\title{
GRAMMAR OF THEOLOGY: LOGICAL ARGUMENTATION FROM ORIGEN TO THE CAPPADOCIAN FATHERS**
}

How much does thought depend on the language which formulates it? Is it possible to think and speak of an incomprehensible God? How can one ensure that theological discourse refers to an ontological reality and does not just manifest the idea of deity inherent in the human mind? All these methodological questions surfaced within different contexts and had long been debated by the Greek philosophers. Naturally enough they reappeared in the Christian agenda once initial efforts had begun towards the systematization and institualization of Christian teaching. The debate initiated by Arius after the Nicene Ecumenical Council, whilst at first more explicitly ontological, turned into a nit-picking discussion of logical and terminological nuances. Despite the fact that one of the main pillars of Eunomian teaching was his language theory, scholars have yet to evince quite as decisively the grammatical nature of the Cappadocian contra-argumentation. It is a purpose of my paper therefore to fill this gap and to sketch an overview of the grammatical argumentation of the Cappadocians. I will show that the principles of their argumentation are rooted in the exegetical techniques of Origen, which emerged from the methodology of Hellenic textual critics and grammarians.

To start, let us recall the linguistic and methodological aspect of the Eunomian teaching. After the Council of Nicaea the question of the correctness of divine names, such as unbegotten, begotten, the Father, the Son, remained unresolved. In particular, no decisive explanation had been given as to what these names really signified. In the First Apology $y^{1}$ Eunomius ridicules people who talk about different significata of the divine names among which he mentions

* Dr Anna Usacheva - Postdoctoral researcher, Aarhus University (Denmark), School of Culture and Society, Department of Theology, Systematic Theology/Dogmatics; e-mail: anna.usacheva@ cas.au.dk.

** The investigation was realized with the assistance of EU financial support (the European Union's Horizon 2020 research and innovation programme under the Marie Skłodowska-Curie grant agreement No 660894).

${ }^{1}$ The citations from Eunomius' works are given from: Eunomius (Bishop of Cyzicus), The extant works, text and transl. by R.P. Vaggione, Oxford 1987. 


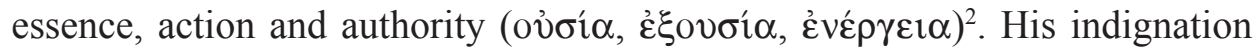
points to the direction of Post-Nicene discussions around the meaning of divine names. For instance, Athanasius of Alexandria in his On the Councils

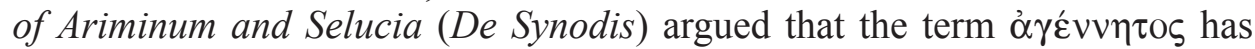
two different but equally valid meanings $(\sigma \eta \mu \alpha \imath v o ́ \mu \varepsilon v \alpha)$ : the first signifying

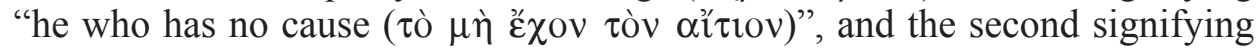
"he who is neither creation $\left(\pi \operatorname{oí}_{\eta} \mu \alpha\right)$, nor generation $(\kappa \tau i \sigma \mu \alpha)$ "). Expectedly enough, this affirmation provoked a set of logical and theological questions concerning the definition of $\tau$ ò $\sigma \eta \mu \alpha \imath v o ́ \mu \varepsilon v o v$, which Eunomius didn't hesitate to ask. Thus, in the First Apology, Eunomius censured people who:

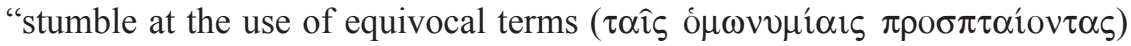

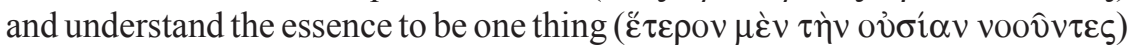

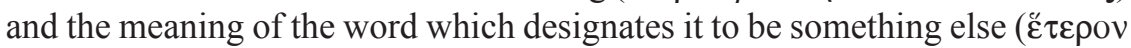

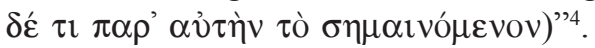

This argument of Eunomius represents a typical example of a Peripatetic criticism of Stoic language theory. Ammonius, in his commentary On Aristotle On Interpretation, affirmed that nouns and verbs directly signify real objects and that "one should not invent anything in between thoughts and real objects

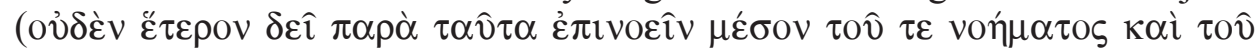
$\pi \rho \alpha ́ \gamma \mu \alpha \tau o \zeta)$ "; likewise the Stoics who invented the notion of $\lambda \varepsilon \kappa \tau o ̀ v^{5}$.

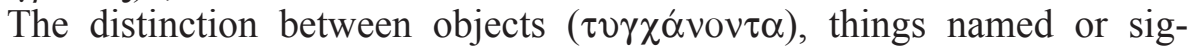

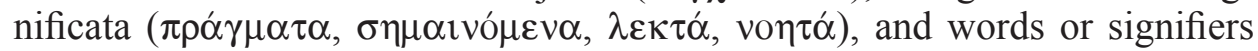
formed the basis of Stoic linguistics. This distinction was adopted by Hellenic grammarians. Pursuing the discussion of the correctness of names, the Stoics reached a compromise solution of this problem ${ }^{6}$, which was also supported by the grammarians ${ }^{7}$. They believed that names are correctly (i.e. $\varphi v ́ \sigma \varepsilon \imath$ ) assigned (i.e. $\theta \dot{\varepsilon} \sigma \varepsilon \imath$ ). They also taught that in the course of time the initial correctness of names, which basically attested an agreement of signifiers and significata, was blurred and such was the provenance of ambiguity and homonymy ${ }^{8}$. It was in conformity with the Stoic linguistics that grammarians believed in

${ }^{2}$ Cf. Eunomius, Liber Apologeticus 12; 21; 24.

${ }^{3}$ Athanasius Alexandrinus, De synodis Arimini in Italia et Seleuciae in Isauria 46, 3, ed. H.G. Opitz, in: Athanasius Werke, vol. 2.1, Berlin 1940, 259, my own translation.

${ }^{4}$ Eunomius, Liber Apologeticus 12, ed. and transl. by Vaggione, p. 49.

${ }^{5}$ Ammonius, In Aristotelis librum de interpretatione commentarius 17, 25, ed. A. Busse: In Aristotelis de interpretatione commentarius, Commentaria in Aristotelem Graeca IV/5, Berlin Reimer 1897, my own translation.

${ }^{6} \mathrm{Cf}$. Diogenes Laertius, Vitae philosophorum VII 57 = SVF II 146.

${ }^{7}$ Cf. Apollonius Dyscolus, De constructione orationis I 2, ed. G. Uhlig, Grammatici Graeci, vol. 2/3, Leipzig 1910, transl. and commentary by W. Householder: The syntax of Apollonius Dyscolus, Amsterdam 1981, 19.

${ }^{8}$ Cf. idem, De pronominibus 38, 22, ed. R. Schneider, Grammatici Graeci, vol. 2/1, Leipzig 1878, transl. and commentary by W. Householder: The syntax of Apollonius Dyscolus, p. 91. 
the sequential provenance of parts of speech ${ }^{9}$, where nouns (personal names and appellatives), which signify substance, are succeeded by verbs signifying a certain state of substance ${ }^{10}$.

Origen generally supported the language theory of Hellenic grammarians. Although he only once referred to $\lambda \varepsilon \kappa \tau \tau \dot{\alpha}$ in the Commentary on Psalms ${ }^{11}$, he rather frequently (more than 100 times) used the term $\sigma \eta \mu \alpha \imath v o ́ \mu \varepsilon v o v$ to designate "significatum". For instance in the Commentary on John he advised a reader of Scripture to distinguish clearly between "the language ( $\varphi \omega \vee \eta)$, meaning $(\sigma \eta \mu \alpha \imath v o ́ \mu \varepsilon v \alpha)$, and things $(\pi \rho \alpha ́ \gamma \mu \alpha \tau \alpha)$, on which the meaning is based"12. In the Commentaries on Genesis, Origen argued for the sequential provenance of parts of speech ${ }^{13}$. He also supported the concept of the pristine language, which somewhat justified his idea of the divine origin of the Hebrew proto-language (viz. before the babble of languages in Gen 11). In such a way he affirmed that some of the Hebrew divine names (like Adonai and Sabaoth) help in the ascendance to $\operatorname{God}^{14}$.

Pondering on this evidence Jean Daniélou and John Dillon assumed that Origen's language theory could be affiliated with the voces magicae concept which emerged from the Chaldean Oracles and was held by the Neoplatonic theurgists ${ }^{15}$. In spite of these beliefs, which, as J. Dillon demonstrated, come really close to the views held by the Neo-Platonists, Origen emphatically renounced the equation of the pagan rituals to the Christian prayer. He underscored the different mechanisms of the pagan and Christian worship ${ }^{16}$. Whatever parallels might be seen between Origen's conjectures on the revelatory origin of the Hebrew proto-language and the concept of voces magicae (lately elaborated by Iamblichus in the De mysteriis with regard to the Greek Magical Papyri ${ }^{17}$ ) the practical appliance of the divine names in prayer and reciting of spells, described by Origen and the Neo-Platonists, reveal an apparent difference of their language theories. In such a way Origen emphasised that Christian prayer stands as far away from the magical spell as the inane sounds from the meaningful words. In the treatise Against Celsus (Contra Celsum) Origen also asserted that magical spell reveals its weakness in translation,

\footnotetext{
${ }^{9}$ Cf. idem, De constructione 4, 10, from: Householder, p. 228-229.

${ }^{10} \mathrm{Cf}$. Diogenes Laertius, Vitae philosophorum VII 57 = SVF II 147-148.

${ }^{11}$ Cf. Origenes, Fragmenta in Psalmos 80, 1, 20.

${ }^{12}$ Origenes, Commentarii in Joannem II 5, 47, ed. C. Blanc, SCh 120, Paris 1966, 236, my own translation.

${ }^{13}$ Cf. idem, Commentarii in Genesim v. 20-25, PG 12, 88.

${ }^{14} \mathrm{Cf}$. idem, Contra Celsum I 24.

${ }^{15}$ Cf. J. Daniélou, Eunome l'arien et l'exégèse néo-platonicienne du Cratyle, REG 69 (1956) 412-432; J.M. Dillon, The magical power of names in Origen and later Platonism, in: Origeniana tertia: the Third International Colloquium for Origen Studies, University of Manchester September 7th-11th, 1981, ed. R. Hanson - H. Crouzel, Roma 1985, 203-216.

${ }^{16}$ Cf. Origenes, Contra Celsum VIII 17-20.

${ }^{17}$ Cf. Dillon, The magical power of names in Origen and later Platonism, p. 207-208.
} 
which renders it powerless, while the Christian prayer remains powerful as long as one who says the prayer does it consciously:

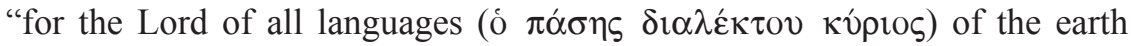
hears those who pray to Him in each different tongue, hearing, if I may so say, but one speech corresponding the meaning ( $\dot{\zeta} \mu \hat{\alpha} \varsigma \varphi \omega v \hat{\eta} \varsigma \tau \hat{\eta} \varsigma \kappa \alpha \tau \dot{\alpha} \tau \dot{\alpha}$

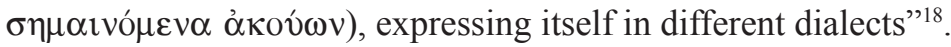

Besides, from Origen's Biblical studies we learn that he had a sober scholarly approach to the common biblical nouns and to the divine names likewise. In the Commentary on John Origen encouraged the exegetes to investigate a contex-

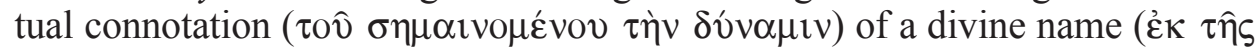
$\varphi \omega \vee \hat{\eta} \varsigma$ ), since this name is meant not only figuratively but literally (ov $\tau \rho \circ \pi \imath \kappa \hat{\omega} \varsigma$

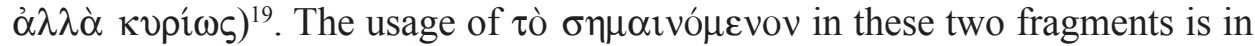
tune with the Stoic understanding of the "thing signified", which belongs to the intellectual reality and implies different connotations; however after actualization in a concrete grammatical context, it receives a literal meaning.

Despite of Origen's leaning towards the Stoic linguistics his language theory embraced different philosophical concepts and hence should not be exclusively affiliated to any of them. However, I believe that a linkage with the relatively independent teaching of grammarians is a crucial component of Origen's linguistic views. Given that the analytical techniques and relevant concepts of the grammarians emerged from their textual critique of the Homeric poems, it is simply natural that a closeness of professional interests (of Hellenic, Jewish and Christian exegetes) resulted in a similarity of their methods.

Now, let us see how the Cappadocians made use of the language theories of the Hellenic grammarians and Origen in their polemics with the Eunomians. Origen, Basil and Gregory Nazianzen in conformity with grammatical theory argued that the essence of a subject can be fully expressed by a predicate. In the Homilies on Jeremiah Origen applied this idea to the scriptural names of Christ saying that though the nature of Christ constitutes a single subject

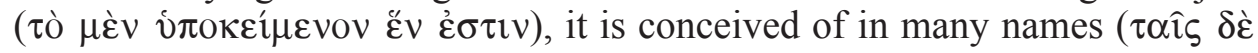

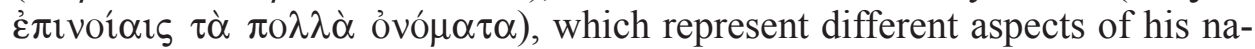
ture $^{20}$. In a similar manner, Gregory Nazianzen in his third theological oration professed that:

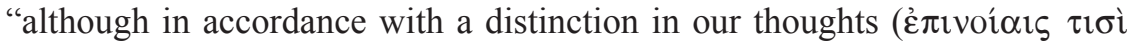
$\delta ı \alpha \imath \rho v \mu \varepsilon ́ v \alpha 1 \varsigma$ ) we use distinct names (ỏvó $\mu \alpha \tau \alpha)$ and that whatever is pro-

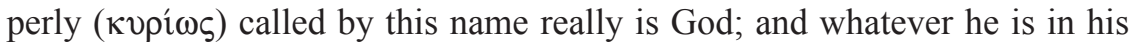

${ }^{18}$ Origen, Contra Celsum VIII 37, ed. M. Borret, SCh 150, Paris 1969, 256, transl. by F. Crombie (with my correction), in: ANF IV, A.C. Coxe - J. Donaldson - A. Roberts, Buffalo - New York $1885,653$.

${ }^{19}$ Idem, Commentarii in Joannem I 21, 125, SCh 120, 126.

${ }^{20}$ Cf. Origenes, In Jeremiam hom. VIII 2, 10-11, ed. P. Nautin, SCh 232, Paris 1976, 357. 
nature (ô $\delta$ ’ $\alpha \hat{~}$

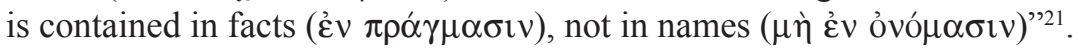

Contemplating the reality beyond the hypostatic names, Basil and Gregory affirmed that the Father and the Son are relative names, which manifest an inherent unity of the divine persons because there is no way of imagining the Father without the Son or vice versa. In the $16^{\text {th }}$ paragraph of De filio Gregory stated:

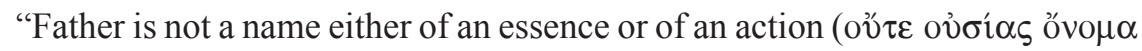
ó $\pi \alpha \tau \eta \dot{\rho} \rho$, [...] o $\left.\tau_{\tau \varepsilon} \dot{\varepsilon} v \varepsilon \rho \gamma \varepsilon i \alpha \varsigma\right)$ [...]. But it is the name of the Relation in which

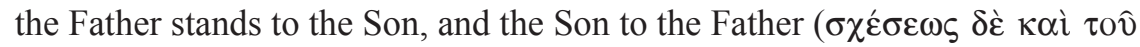

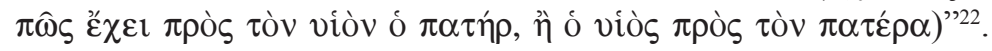

To clarify this statement, Gregory explained the term "relation" in conformity with Hellenic philosophical tradition ${ }^{23}$. He affirmed that a mere idea of the

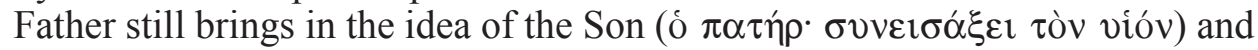
this fact of the relative connection between the ideas produces no changes in either of them, or as Gregory puts it:

"will not make it of a different nature, according to common ideas and the

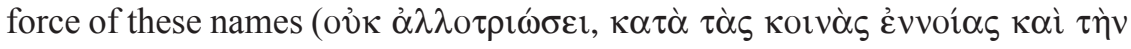

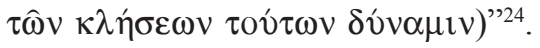

In order to understand precisely this relative mode of the Father-Son relationship we must establish a philosophical pattern of the relationship between essence and hypostasis. It was again Origen who introduced the term hypostasis in Christian theology ${ }^{25}$, while the Stoics instituted the notion in a philosophical context ${ }^{26}$.

Posidonius (131-51 BCE) defined hypostasis as an actualized being which comes into existence to manifest the eternal essence and its individual qualities in real phenomena. According to a paraphrase of Arius Didymus $\left(1^{\text {st }}\right.$ century BCE-CE), Posidonius:

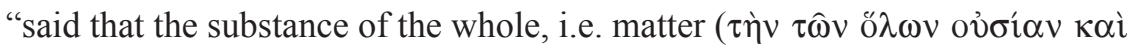
¿ $\lambda \eta v$ ) was without quality and without shape, in so far as in no way has it

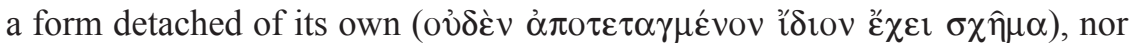

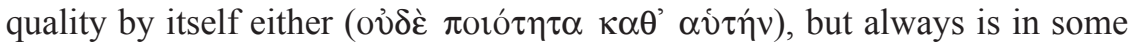

\footnotetext{
${ }^{21}$ Gregorius Nazianzenus, Oratio 29 (De Filio), 13, 15-20, ed. P. Gallay, SCh 250, Paris 1978, 204, transl. by L. Wickham - F. Williams: Faith gives fullness to reasoning: the five theological orations of Gregory Nazianzen, introduction and commentary by F.W. Norris, Leiden 1991, 253.

${ }^{22}$ Ibidem 29, 16, SCh 250, 210, transl. by C.G. Browne - J.E. Swallow, NPNF Ser. II, vol. 7 , ed. P. Schaff - H. Wace, Buffalo NY 1894, 307.

${ }^{23}$ Cf. Simplicius, In Aristotelis categorias commentarium VIII 166, 15-27.

${ }^{24}$ Gregorius Nazianzenus, Oratio 29 (De Filio), 16, SCh 250, 210, transl. by C.G. Browne - J.E. Swallow, NPNF Ser. II, vol. 7, p. 307.

${ }^{25}$ Cf. Lampe, s.v. í ó $\sigma \tau \alpha \sigma i \varsigma$.

${ }^{26}$ Cf. H. Köster, vं
} 


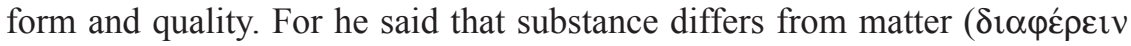

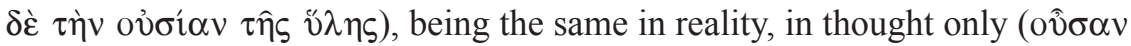

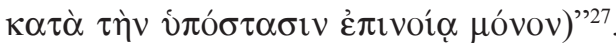

This distinction between the ov่ $\sigma i \alpha$ and $v \pi$ ó $\sigma \tau \alpha \sigma ı \varsigma$ gave rise to a tricky problem that concerned the understanding of hypostasis as an actualization of essence in its qualities. Thus, hypostasis was considered as something that manifests essence and at the same time is different from it. The qualities were understood as the functional characteristics of essence. A detailed explanation of this vision of essence is preserved in Origen's Homily on Prayer:

"By qualities ( $\pi$ otó $\tau \tau \alpha \varsigma)$ they mean distinctively like the actualities and the

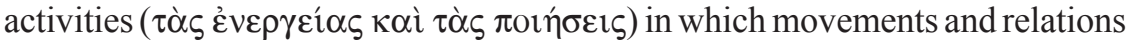

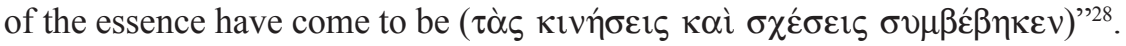

Interestingly enough this complex vision of the essence, which exists behind the real objects and actualizes itself in them, finds an echo in the sphere of logic and grammar. An informative account of this concept is preserved in Dexippus' fourth-century Commentary on Categories ${ }^{29}$. Dexippus stated that

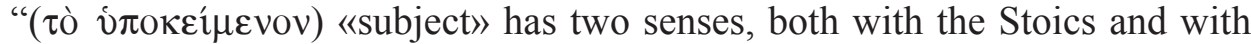
the older philosophers (the Peripatetic and the Old Academy)" 30 . I have formalized his evidence in the following table:

\section{$\underline{1}^{\text {st }}$ sense of subject ( $\pi \rho \hat{\omega} \tau O \nu$ í $\left.\pi \circ \kappa \varepsilon i ́ \mu \varepsilon v o v\right)$ :} qualityless matter $(\dot{\eta} \ddot{\alpha} \pi 010 \varsigma$ $\ddot{\lambda} \lambda)$

$=$ a subject of proposition $=$ potential body $(\delta v v \alpha ́ \mu \varepsilon \imath \sigma \hat{\omega} \mu \alpha), e . g .$, it $(\tau i)$

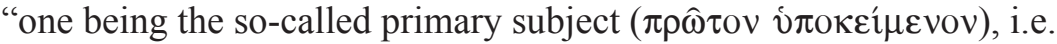

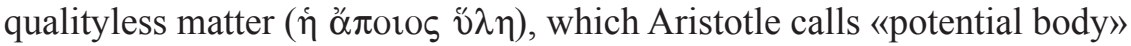

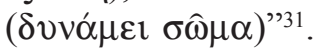

$\underline{2}^{\text {nd }}$ sense of subject: qualified subject (

$=$ actualization $\left(\hat{v} \pi \delta \sigma_{\tau} \alpha \sigma \imath \varsigma\right)$ of the subject in the qualities, which are predicated of the subject (relative terms $\pi \rho{ }^{\prime} \varsigma \tau \imath \lambda \dot{\varepsilon} \gamma \varepsilon \sigma \theta \alpha \imath$ ), e.g., the bronze "and the second type of subject is the qualified subject

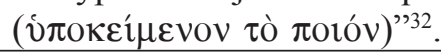

${ }^{27}$ Arius Didymus, Epitome Fr. 20 (apud Stobaeus, Eclogae I, 133 W; Dox. Gr. 458), in: Posidonius Rhodius, Fragmenta, Fr. 92, ed. and transl. I.G. Kidd: Posidonius, vol. II: The Commentary, part 1: Testimonia and fragments 1-149, Cambridge 1989, 368; vol. III: The Translation of the Fragments, Cambridge 1999, 152.

${ }^{28}$ Origenes, De oratione 27, 8, ed. P. Koetschau, GCS 3, Leipzig 1899, 368, transl. by W.A. Curtis: http://www.tertullian.org/fathers/origen_on_prayer_02_text.htm [15.09.2016].

${ }^{29}$ Cf. Dexippus, In Aristotelis categorias commentarium 23, 25 - 24, 4.

${ }^{30}$ Ibidem 22-24, ed. A. Busse: Dexippi in Aristotelis categorias commentarium, Commentaria in Aristotelem Graeca IV/2, Berlin 1888, 23, transl. by Dillo: Dexippus, On Aristotle Categories, London - New York 1990, 50-51.

${ }^{31}$ Ibidem.

${ }^{32}$ Ibidem. 


\section{general or individual qualities ( \\ e.g., the bronze of statue (general), or the bronze of the statue of Socrates (particular)}

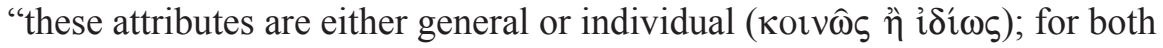

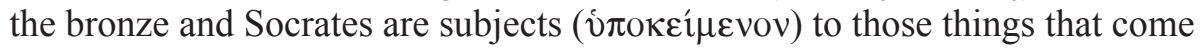

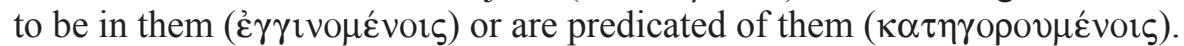

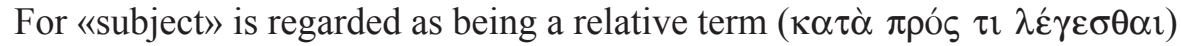

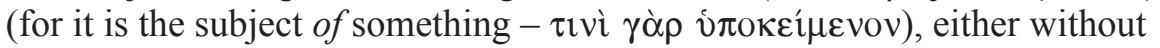
qualification, of those things that come to be in it and are predicated of it, or in a particular sense" 33 .

This concept of essence, which finds its actualization in the qualities of real things, fitted a complex Christian vision of the divine essence. Basil used this idea in his polemics with Eunomius and for a formulation of his Christological teaching. In the Letter 38, he professed:

"That which is spoken of in the specific sense ( $\tau$ ò i $\delta i \omega \varsigma \lambda \varepsilon \gamma o ́ \mu \varepsilon v o v$ ) is signi-

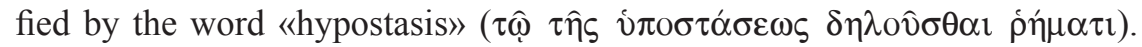
For, because of the indefiniteness of the term, he who says «man» has introduced through our hearing some vague idea, so that, although the nature is

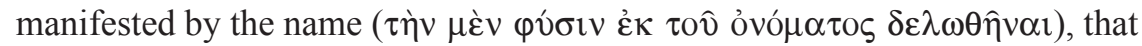

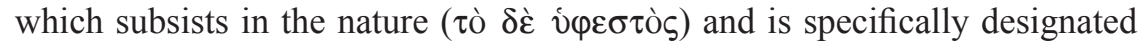

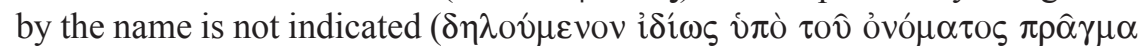

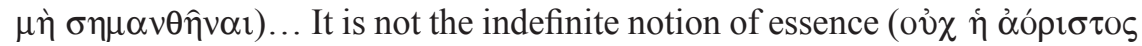

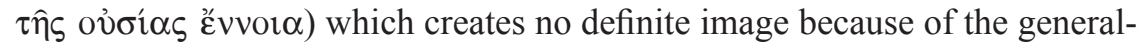

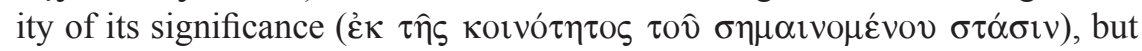
the hypostasis, which is evident through the specific qualities" ${ }^{\prime 3}$.

In conformity with Basil, Gregory Nazianzen also used the category of "relation" $(\sigma \chi \hat{\eta} \sigma \mathrm{\iota} \varsigma)$ in his formulation of Christological doctrine. In the second theological oration he affirmed:

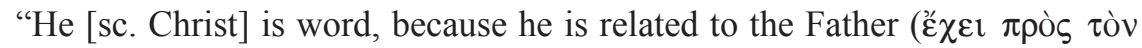

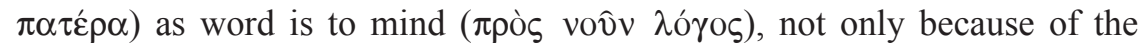

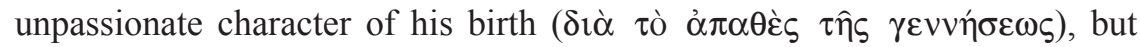
also because of the conjunction and conveying peculiar to this relationship

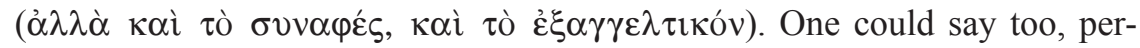

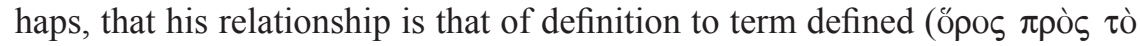

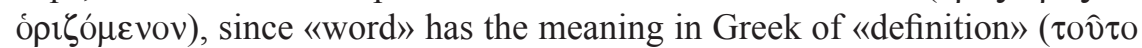
$\lambda \varepsilon \dot{\gamma \varepsilon \tau \alpha(\lambda o ́ \gamma O \varsigma)}{ }^{\prime \prime 35}$.

${ }^{33}$ Ibidem.

${ }^{34}$ Basilius Caesariensis, Epistula 38, 3, 1, PG 32, 328, transl. by B. Jackson, NPNF Ser. II, vol. 8, ed. Ph. Schaff - H. Wace, New York 1895, 137.

${ }^{35}$ Gregorius Nazianzenus, Oratio 30 (De Filio), 20, SCh 250, 266-268, transl. by Wickham - Williams, p. 179. 
Now, having examined the logical and grammatical aspects of the argumentation of Origen, Basil and Gregory, let us return to the questions we posed at the beginning of this article and try to speculate on the answers which they might have given to them. How much does thought depend on the language which formulates it? From the evidence we have assembled above, it is apparent that Origen, Basil and Gregory supported the linguistic theories of the Hellenic grammarians, who believed in a direct and fundamental connection between language and thought. Ergo, the logical and grammatical rules of the correct formulation of thought likewise regulate the mental procedures.

A backbone of Apollonius' syntaxis constituted an idea that regular orga-

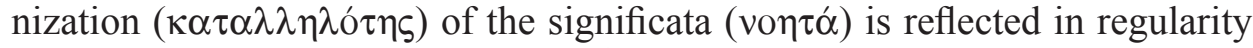
of the signifiers (sc. $\varphi \omega \vee \alpha^{\prime}$, words $)^{36}$. It is notable that a derivate of a rather

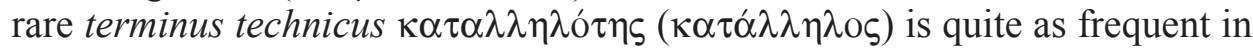
Origen's opera as in Apollonius. A belief in the orderly organization of the universe also formed a foundation of Origen's systematic theology. In the Commentary on John Origen affirmed that the whole Bible is one body, whose parts form a harmonious unity that is the word of God, which "consists of many ideas each of which is a part of the whole word" "37. Gregory Nazianzen articulated even more clearly the concept of the fundamental orderly organization of the universe, which is mirrored in the systematic organization of knowledge. In his Oration $32^{38}$ he declared that:

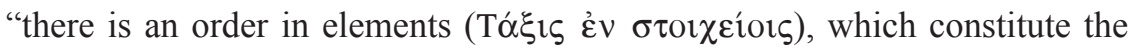
bodies $(\hat{\varepsilon} \xi \hat{\omega} \nu \tau \dot{\alpha} \sigma \omega ́ \mu \alpha \tau \alpha)$... It was order, then, that assembled the whole

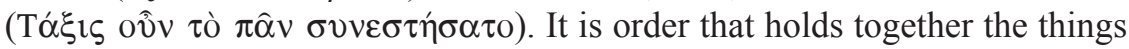
of heaven and the things of earth; order among the things we perceive with

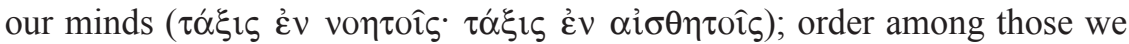
perceive with our senses" 39 .

It should not be overlooked however that the system or order which Origen and Gregory were talking about was a paradoxical one and this distinguished it from the syllogistic teaching of Eunomius. An axiomatic belief in the incomprehensibility of the divine essence rendered the logical and grammatical theological arguments of Origen and the Cappadocians as legitimate as one can expect to draw from the systematic philological analysis of the text. Thus, I would imagine that their response to our last question: How to think and speak of incomprehensible God and How to make sure that theological discourse

\footnotetext{
${ }^{36}$ Cf. Apollonius Dyscolus, De constructione orationis 2, 3ff., transl., by Householder, p. 90.

${ }^{37}$ Origenes, Commentarii in Joannem X 18, 107, ed. C. Blanc, SCh 157, Paris 1970, 446, my own translation.

${ }^{38}$ Cf. Gregorius Nazianzenus, Oratio 32 (De moderatione in disputando), 24-25.

${ }^{39}$ Gregorius Nazianzenus, Oratio 32 (De moderatione in disputando), 8, ed. P. Gallay, SCh 318, Paris 1985, 100, transl. M. Vinson: Gregory of Nazianzus, Select orations, Washington D.C. 2003, 196.
} 
refers to an ontological reality and does not just manifest the idea of deity inherent in the human mind? - might address a principal distinction between comprehensible and incomprehensible knowledge. According to Origen and the Cappadocians, comprehensible knowledge about God that one can extract from a philological analysis of the text of the Bible and incomprehensible knowledge about God cannot be rendered in words. Peculiarly consonant with Ludwig Wittgenstein's famous motto (Tractatus Logico-Philosophicus 7): "Whereof one cannot speak, thereof one must be silent" ${ }^{40}$, Gregory in his second theological oration stated that: "Since the divine essence is ineffable, we

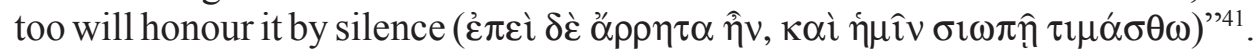

\section{(Summary)}

The article outlines the philosophical and linguistic background of the PostNicene theological debates concerning the relationship between the Father and the Son. A sharp focus dwells of the provenance of the term hypostasis, the philosophical and grammatical understanding of the terms hypokeimenon and ousia and the Stoic definition of the signifier and thing signified. The article shows new aspects of the anti-Eunomian polemics of the Cappadocian fathers, which come into sight due to comparison of theological concepts with Hellenic linguistic and grammatical theories. In such a way, the comparison demonstrates methodological and technical strand of the theological argumentation of the Cappadocian fathers and their affinity for the exegetic methodology of Origen.

\section{GRAMATYKA TEOLOGII: LOGICZNA ARGUMENTACJA OD ORYGENESA DO OJCÓW KAPADOCKICH}

\section{(Streszczenie)}

W artykule przedstawiono filozoficzne i językowe tło ponicejskich debat teologicznych dotyczących relacji między Ojcem i Synem. Starano sięzwłaszcza uwypuklić następujące zagadnienia: pochodzenie terminu hipostaza, filozoficzne i gramatyczne rozumienie określeń hypokeimenon i ousia oraz stoickie definicje: ,element oznaczający” i ,rzecz oznaczana”. W artykule przedstawiono nowe aspekty antyeunomiańskiej polemiki Ojców Kapadockich, które wynikają na skutek porównania pojęć teologicznych z greckimi teoriami językowymi i gramatycznymi. Takie porównanie ukazuje metodologiczny i techniczny aspekt argumentacji teologicznej Ojców Kapadockich, a także ich bliskość z metodologią egzegetyczną Orygenesa.

${ }^{40}$ L. Wittgenstein, Tractatus Logico-Philosophicus, with an introduction by B. Russel, New York 1922, 90 .

${ }^{41}$ Gregorius Nazianzenus, Oratio 28 (De theologia), 20, SCh 250, 140, transl. by Wickham - Williams, p. 122. 
Key words: theological concepts, linguistic theories, Stoicism, Origen, Cappadocian Fathers.

Słowa kluczowe: pojęcia teologiczne, teorie językowe, stoicyzm, Orygenes, Ojcowie Kapadoccy.

\section{BIBLIOGRAPHY}

\section{Sources}

Ammonius, In Aristotelis librum de interpretatione commentarius, ed. A. Busse: In Aristotelis de interpretatione commentarius, Commentaria in Aristotelem Graeca IV/5, Berlin 1897.

Apollonius Dyscolus, De constructione orationis, ed. G. Uhlig, Grammatici Graeci, vol. 2/3, Leipzig 1910, 1-497, transl. and commentary by W. Householder: The syntax of Apollonius Dyscolus, Amsterdam 1981.

Apollonius Dyscolus, De pronominibus, ed. R. Schneider, Grammatici Graeci, vol. 2/1, Leipzig 1878, 3-116.

Arius Didymus, Epitome Fr 20, in: Posidonius Rhodius, Fragmenta, ed. and transl. I.G. Kidd: Posidonius, vol. II: The Commentary, part 1: Testimonia and fragments 1-149, Cambridge Classical Texts and Commentaries 14A, Cambridge 1989; vol. III: The Translation of the Fragments, Cambridge Classical Texts and Commentaries 46, Cambridge 1999.

Basilius CAesariensis, Epistulae, PG 32, 219-1112, transl. by B. Jackson, in: NPNF II/8, ed. Ph. Schaff - H. Wace, New York 1895, 109-327.

Dexippus, In Aristotelis categorias commentarium, ed. A. Busse: Dexippi in Aristotelis categorias commentarium, Commentaria in Aristotelem Graeca IV/2, Berolini 1888, transl. by J. Dillon: Dexippus, On Aristotle Categories, London - New York 1990.

Diogenes Laertius, Vitae philosophorum, ed. H.S. Long: Diogenis Laertii vitae philosophorum, vol. 1-2, Oxford 1964.

Eunomius, Liber Apologeticus, ed. and transl. by R.P. Vaggione, in: Eunomius, The Extant Works, Oxford 1987, 34-74.

Gregorius Nazianzenus, Orationes 27-31, ed. P. Gallay, SCh 250, Paris 1978; 32-37, ed. P. Gallay, SCh 318, Paris 1985, transl. by C.G. Browne - J.E. Swallow, NPNF Ser. II, vol. 7, ed. P. Schaff - H. Wace, Buffalo NY 1894; transl. by L. Wickham - F. Williams: Faith gives fullness to reasoning: the five theological orations of Gregory Nazianzen, introduction and commentary by F.W. Norris, Leiden 1991; transl. by M. Vinson: Gregory of Nazianzus, Select orations, Washington D.C. 2003.

Origenes, Commentarii in Genesim, PG 12, 45-92.

Origenes, Commentarii in Joannem I-V, ed. C. Blanc, SCh 120, Paris 1966; VI, X, ed. C. Blanc, SCh 157, Paris 1970.

Origenes, Contra Celsum I-II, ed. M. Borret, SCh 132, Paris 1967; III-IV, SCh 136, Paris 1968; V-VI, SCh 147, Paris 1969; VII-VIII, SCh 150, Paris 1969; transl. by F. Crombie, in: ANF IV, ed. A.C. Coxe - J. Donaldson - A. Roberts, Buffalo - New York $1885,395-669$.

OrIGENes, De oratione, ed. P. Koetschau, GCS 3, Leipzig 1899, 295-403, transl. by W.A. Curtis: http://www.tertullian.org/fathers/origen_on_prayer_02_text.htm [15.09.2016].

Origenes, In Jeremiam hom., ed. P. Husson - P. Nautin, t. 1, SC̄h 232 Paris 1976; t. 2, SCh 238, Paris 1977. 
Simplicius, In Aristotelis categorias commentarium, ed. K. Kalbfleisch: Simplicii in Aristotelis Categorias commentarium, Commentaria in Aristotelem Graeca VIII, Berlin 1907, 1-438.

\section{Literature}

DANiÉLOU J., Eunome l'arien et l'exégèse néo-platonicienne du Cratyle, REG 69 (1956) 412-432.

Dillon J.M., The magical power of names in Origen and later Platonism, in: Origeniana tertia: the Third International Colloquium for Origen Studies, University of Manchester September 7th-11th, 1981, ed. R. Hanson - H. Crouzel, Roma 1985, 203-216.

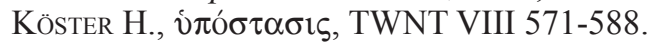

LAMPe G.W.H., A Patristic Greek Lexikon, Oxford $1976^{4}$.

Wittgenstein L., Tractatus Logico-Philosophicus, with an introduction by B. Russel, New York 1922. 
